\author{
Article type: Focus Article
}

\title{
The role of spatial planning in adapting to climate change
}

Published in 2012, 3(5) 477-488.

*Anna C Hurlimann, Faculty of Architecture Building and Planning, The University of

Melbourne, Australia 3010; hurac@unimelb.edu.au

Alan P March, Faculty of Architecture Building and Planning, The University of

Melbourne, Australia 3010

\begin{abstract}
Spatial planning has been identified as a critical mechanism through which climate change adaptation can be facilitated. We review the role of spatial planning as a tool for adaptation to climate change. In doing so, we describe common planning processes and tools. Six capacities of spatial planning that have the potential ability to facilitate climate change adaptation are identified and discussed. These principally relate to spatial planning's ability to: act on matters of collective concern; manage competing interests; cut across scales; reduce and act on uncertainty; act as a knowledge repository; and be oriented to the future while integrating a range of diverse systems. Methods (tools) for adaptation planning which have the capacity to address climate change adaptation are presented and discussed. In light of these capacities and acknowledged limitations in planning practice, we identify three key challenges to spatial planning for adaptation: 1) developing conviction; 2) facilitating equitable processes and outcomes, and 3) transforming planning systems from passive to proactive.
\end{abstract}

Spatial planning ${ }^{1}$ (herein referred to as 'planning') has been acknowledged to have a critical role to play in addressing both the mitigation of climate change, and adaptation to its unavoidable impacts [1-10]. This view is drawn from recognition that the spatial configuration of cities and towns, and the way in which land is used and developed have significant impacts on climate change [5], and will be central to enacting adaptive responses to this change [11-14]. Importantly, contemporary empirical research has found that planning institutions are critical drivers of adaptation to climate change [11, $15,16]$. A recent review of the role of law in adapting to climate change identified land use planning as the most effective tool to reduce exposure and sensitivity to extreme weather events in many instances [17]. Indeed in Victoria, Australia there have been a number of planning legal appeals, the determinations of which have had implications for spatial planning considerations for climate change 
adaptation to sea level rise $[18,19]$. In theory, planning appears well equipped to deal with adapting to the impacts of climate change ${ }^{2}$. This is because central to planning practice is knowledge of present conditions, and an ongoing orientation to seeking future improvements while avoiding emergent problems, on the basis of collective responsibility [20].

Despite this touted role for planning in addressing climate change adaptation, there is not universal agreement [21]. For example, while Howard [22] advocates that planning can make a positive contribution toward adapting to and mitigating climate change, he highlights that planning systems have in the past delivered policy which has been detrimental for climate change. Outcomes have included: suburban sprawl, building codes oblivious to energy efficiency, automobile obsession, reliance on fossil fuels and failure to consider urban environmental externalities. Additionally, the UK Government labeled planning as 'the problem' in the case of hold ups in implementing wind farms [4]. On the contrary, Bulkeley [5] details the extent to which national planning guidance in the UK (detailed well in [23]) directs the consideration of climate change, and places it as a central issue. Despite these and other criticisms and acknowledged limitations [e.g see 14], we consider that planning can play a positive and important role in adapting to climate change. We also acknowledge that planning can not address the challenges of climate change adaptation alone. Planning is only one part of the adaptation process and needs to be integrated with other means available to society $[4,24]$.

We begin this paper by providing an overview of planning. In doing so we highlight a well known model which guides planning activities, and we present some common planning tools. We then identify and discuss the functionalities of planning which have the capacity to facilitate adaptation. Following this we offer a suite of general methods for planning for climate change adaptation. We finish by presenting and discussing three key challenges to planning for adaptation.

It must be acknowledged from the outset that a there is a paucity of academic research and literature on the role of spatial planning in developing both mitigation and adaptation strategies to address climate change [25]. This may arise in part because, as a recent meta analysis shows, there are few adaptation processes underway in developed nations [26] and that limited attention has been paid to the experiences of adapting to climate change [27]. As Davoudi et al. [25] point out, in comparison to the boom in scientific literature, papers in the field of planning and climate change are 'limited and disparate'. Our assessment of the literature in early 2012 indicates that the situation has not significantly improved. While books have been written and compiled, even including 'climate change' and/or 'planning' in the title [21, 28-30], as well as numerous journal articles, most do little to address the substantial role planning has to play in addressing this key global challenge, and they fail to engage with the detailed substantive issues at stake (notable exceptions include $[4,25]$ ).

\section{Spatial Planning}

Historic evidence of planning dates back to the first intensively developed settlements of early civilizations, such as in southern Mesopotamia, Egypt, China and Mexico [31]. Planned rather than organic growth has always been characterized by one or more key elements of conscious governance: productivity gains based on setting out roads, market places, manufacturing and agricultural areas; religious representation and activity; formalized land ownership and patterns, and 
decision systems for development; defence; imposed street patterns; aesthetic or safety codes; and, infrastructure provision [32].

Modern planning emerged after the European Industrial Revolution [20] and has been taken up globally in locally particular ways since that time. Responding to the problems emerging from rapid urbanization and growth, modern planning has its basis in seeking to protect health and well-being; provision of reticulated sewerage; control of sprawl, location of industry, and the creation of pleasing aesthetics. More recent focuses have included environmental protection, public participation and the imperative of sustainable development $[33,34]$. Planning initially came to be characterized by Health and Building Acts as parliaments sought to deal with emergent problems resulting from industry and commercialisation of housing. Internationally, considerable work on ideal settlement forms was undertaken, such as Ebenezer Howard's Garden City [35], or the Chicago Plan of 1909 [36]. The most significant breakthrough was Patrick Geddes' concept of gathering and analyzing evidence as the basis for plans that anticipates trends encapsulated in the maxim: Survey-AnalysisPlan [37]. From this beginning, planning capabilities and agencies were developed at local, regional and even national scales, usually associated with other government functions and bureaucracies. In parallel, the profession of planning emerged, with mixed origins in the disciplines of architecture, engineering, surveying, landscape architecture, geography and health [38, 39].

The rational comprehensive planning model establishes a procedure for planning, which offers a 'rational' alternative to the physical planning reliance on the earlier Survey-Analysis-Plan [40: 66-7]. The model is simple at a conceptual level and provides concrete methods and approaches in the complex [41] reality of planning situations. Despite considerable critique over time, variations to rational comprehensive planning remain the most commonly practised and taught planning theory [42, 43: 21]. Originating in the policy analysis and business world [44], the rational comprehensive process follows six sequential (linear) steps (elements) which are now articulated in many ways across the literature and in different settings [45] seeking to address shortcomings in evidence and attention. They are illustrated in Figure 1. For example, characteristics of these steps have been identified as missing from best practice guidance on coastal adaptation to climate change, and are a recommended adaptation to this process [46]. In settings such as these, planning processes have often fallen short of the ideal due to complications such as fragmented or contested land ownership, place attachment, issues of compensation, and lack of resources, expertise or authority. In the wider area described as public policy, and in which planning is included, similar approaches in policy development and implementation are used [47] seeking to strengthen legitimacy.

$<$ Insert Figure 1>

Developed from $[45,48]$

The rational comprehensive process, while the most commonly practised planning approach (if often in truncated ways) now has multiple rivals, adaptations and alternatives. In practice, as new approaches are developed, they are added as "layers" over time to the ways that planning is practised, rather than replacing them. For example, systems planning is closely related to rational comprehensive planning, but is more directly based upon the gathering and modelling of large data sets with the intent of determining how overall systems can be managed to produce desirable 
changes $[49,50]$. The difficulties of data collection, limited computing abilities and modeling challenges, combined with political and social unrest in the 1960s and 1970s, led to considerable critique. A resurgence of interest in systems approaches has recently been fuelled by wider recognition of the interconnectedness of socio-economic and ecological systems, combined with vastly improved computing powers [51].

Advocacy planning sought to directly identify sections of the community or causes that were underrepresented and for planners to actively advocate on their behalf [52, 53]. Neo Marxist planners challenged the 'tying' of planning to economic production and capitalism, which they argued meant that planning was reinforcing ongoing inequity [54]. In contrast, neoliberal approaches have also been critical of planning's role in market systems, but from the alternative view that it should only intervene when moderating problems that market-based approaches cannot resolve. Neo-liberal approaches seek the best of market-delivered planning systems, grudgingly seeing planning only as a way of fixing "market failure" [55]. Feminists considered cities and planning as sites of female oppression [56], a sentiment taken up by postmodernists seeking to oppose the homogenizing and oppressive tendencies of large scale, male and 'white' planning to champion and recognize difference [57-59].

Additionally, the recognition that planning is carried out through governance mechanisms led some to seek management approaches such as "muddling through" via incremental change management [60]. As a way of dealing with excessively large data sets and choice "mixed scanning" sought to consider wide views to determine areas of concern, then to examine and manage more specific components on the basis of this intelligence [61]. Collaborative or communicative planning is a broad body of work that seeks to embrace and improve the shared and often discursive nature of plan production and implementation $[62,63]$.

The actual functions of planning can be carried out via a diverse range of institutional forms, which vary from nation to nation and jurisdiction to jurisdiction. Importantly, planning requires the ability to make plans, and to implement these. To do so, planning systems rely on some form of statutory 'force,' typically derived from legislation, that provide them with decision-making powers [64]. Indeed the appropriate statutory force has been found to be important in related fields such as the achievement of sustainability principles $[29,65]$. These decision making powers allow planning agencies to establish visions and scenarios for the future, carry out urban projects, write policies, strategise to deal with emergent opportunities and problems, and to design specific aspects in detail should it be necessary (see Table 1) [66]. These planning tools can be used to guide urban change to achieve social, economic, and environmental benefits.

\section{<Insert Table 1>}

Planning is typically implemented across various levels of government. Local government authorities are often principal agents of the implementation of planning as they are the level of government 'closest to the ground,' with the best links to place. Importantly, the actions of local government and at local levels are viewed as having critical influence to climate change adaptation [14, 67-69]. Yet despite this, and the increasing imperative to adapt, it appears actions by local governments have to date largely focused on their role in reducing greenhouse gas emissions - hence mitigation [11]. Evidence suggests that in practice most local governments have not begun to specifically address climate change adaptation in their plans [15, 70-72]. Where adaptation actions have been 
initiated they are often fragmented, and do not address the key drivers and determinants involved [73]. However, there are notable examples of local government adaptation actions [13, 74]. Importantly, planners need to be aware that there are often conflicts and contradictions between adaptation and mitigation policies $[75,76]$.

Two fundamental aspects of planning are important in thinking about the challenge of adapting to climate change. One is planning's orientation to the future, combined with the potential to coordinate, spatially and functionally, the activities of a range of actors to achieve long terms benefits. Two is that planning is located 'within' government, on behalf of a range of people, over the long term and with uncertain future challenges and resultant outcomes. Accordingly it is often difficult to develop plans and to then carry them out [41]. Additionally planning has to work through markets and politics. In the context of climate change, planning is faced with multiple threats that relate to human settlements, the impacts that settlements have on climate change, and that climate change will have on them.

\section{The capacity of spatial planning to address adaptation}

Planning has the capacity (functionality) to facilitate climate change adaptation in a number of ways. We identify six capacities of planning (foreshadowed in Sidebar 1) which we discuss in turn below.

\section{The capacity of spatial planning for adapting to climate change}

1. Planning has the ability to act on and coordinate matters of collective concern or public good

2. Planning can manage and facilitate the consideration of competing interests

3. Planning is a way of thinking and action across various spatial, temporal and governance scales while understanding and acting on local circumstances and particularities

4. Planning can reduce or modify uncertainty and provide new mechanisms to deal with changing circumstances

5. Planning has the capacity to be a repository for spatial knowledge sets

6. Planning is oriented to the future, and has the potential to coordinate the activities of a range of actors to achieve long terms benefits

Planning has the ability to act on and coordinate matters of collective concern or public good [20]. Indeed, the origins and ongoing rediscovery and redefinition of planning over time as new challenges emerge consistently demonstrate [77] its role in determining spatial solutions which make the most 'sense' [62] or represent the 'best' collective solution, despite the challenges this entails [78]. Additionally, climate change raises new questions about the nature of public interest, citizenship and responsibilities to others [4], including the need to more explicitly consider the needs of future generations. Planning offers means of addressing these important issues.

Crucially, planning can manage and facilitate the consideration of competing interests - potentially in ways that improve claims for legitimacy, rigor and impartiality [77]. This is critically important for climate change adaptation decisions given the multiple and conflicting considerations at play in any 
one setting at any one time [79]. These competing interests are anticipated to bring tensions to light between economic, social and environmental dimensions of sustainable development [79].

Significantly, planning is a way of thinking [78] and acting across various spatial, temporal and governance scales while understanding and acting on local circumstances and particularities [80]. This is particularly important since planning provides opportunities to consider, assess and decide upon alternative future scenarios. A common theme to emerge from adaptation literature is the need to integrate the scales of planning decision making to effectively address the challenges of climate change $[4,81]$. This is vital for adaptation, because it must occur (and is occurring) across a range of different spatial, temporal and governance scales [11, 82-84]. Additionally, it has been identified that adaptation should optimally be designed and delivered in local contexts $[15,16,85]$ to respond appropriately and be effective in the long-term.

In ideal settings, planning can reduce or modify uncertainty and provide new mechanisms to deal with changing circumstances [86]. This is critically important for adaptation where additional challenges are presented by uncertainty surrounding scientific information about climate change impacts $[14,84,87,88]$, and human dimensions such as vulnerability and societal responses [89]. Additionally, it has been identified that adaptation will require new tools in some instances [90] as well as flexible policies that can be easily adapted to unanticipated change [46, 91].

Importantly, planning has the capacity to be a repository for spatial knowledge sets, developing knowledge [92]. While there is a significant body of technical information on the impacts of climate change at a global level, a recognised key challenge faced in adapting to climate change is the lack of information available at smaller scales (e.g. national, regional and local levels) [93-95]. A recent critique of this 'global kind of knowledge' identifies that this knowledge is 'brittle' erasing difference and collapsing meaning [96]. Additionally, it has been identified that the 'social' aspects of climate change, while central to climate change adaptation to date, have been largely invisible, apart from the field of economics $[96,97]$. Planning can be a way to overcome these shortcomings of current knowledge.

Lastly, planning is oriented to the future, and can draw together and influence a range of different systems (which are developed and managed by a diversity of disciplines). Planning's orientation to the future is critical for adapting to climate change, given the impacts of current behaviours will manifest in the future. Planning's ability to work across systems and disciplines has been demonstrated as a key aspect of climate change adaptation in the Netherlands. In that context, planning was seen to have a crucial role to play in adapting traditional water management paradigms to respond to climate challenges [12]. In this setting climate change strengthened the environmental dimension of planning and became a new rationale for coordinating actions and integrating different policy priorities [25]. On the flip side, when this is not done effectively adaptation barriers can be formed as has been highlighted in one adaptation case study [13].

\section{Methods for adaptation planning}

Building on the description of common planning tools in Table 1, we provide examples of how these would be translated into methods for adaptation planning. In Table 2 we provide a description of 
how these tools would be applied to adaptation, discuss how they might be translated in practice, how and when they could be used, and identify ways in which these tools can be both positively and negatively captured (pros and cons). Ideally these tools would be implemented sequentially. However, we separate them in Table 2, acknowledging that in reality integration often doesn't occur. As previously discussed, planning tools are part of larger sets of government policy, integrated within this wider policy context.

<Insert Table 2>

Our discussion of the associated cons of each of the six planning tools which could be used to facilitate adaptation, acknowledges many of the daily realities of planning, and its inextricable link with political systems. Additionally, climate change adaptation is just one of numerous important issues that planners must address. Thus while there might be a theoretically ideal adaptation action, the actual solution chosen may depart from this ideal because it is chosen in the context of multiple competing interests planning deals with at any one point. Competing factors may dominate in the short term - e.g. economic development for developing nations [6]. Given these contextual issues, there is an identified benefit of improving the link between climate change policies and broader sustainable development policies [5, 98-100]. It is partly from our discussion of the potential of these planning tools for adapting to climate change (in Table 2), that we identify three key challenges to spatial planning for adaptation.

\section{Challenges to spatial planning for adaptation}

Recognising the realities of planning identified above, and in the potential of planning tools discussed in Table 2, we have identified three key challenges to spatial planning for adaptation. These challenges are derived from real world issues that impact planning practice. We acknowledge that there are many challenges to spatial planning for adaptation, which are not acknowledged here. We have chosen to highlight three which are oriented towards key themes.

\section{Challenge 1: Developing conviction}

Developing political and collective conviction regarding the necessity to adapt (and do so now) is a key challenge to spatial planning's ability to address adaptation. As we have identified in Table 2, planning is exercised within and through government, and is subject to political processes [62, 101, 102], and can be captured by competing political ideologies. Recent acknowledgement that the present generation - not some far distant generation - will experience climate change impacts [103], should help develop conviction to adapt on all levels, by various actors.

As identified in Sidebar 1, planning relies on drawing together a range of actors (including those of a political nature) through different systems, markets and collective choice. However, there is a point where decisions need to be made for, and on behalf of groups at various scales (time; spatial). Drawing from Table 2, 'strategy planning', with its provision of a base for decisions that may be unpopular for some, but are justified collectively or in the longer term, is one example of how planning could materially attempt to address this challenge. 
Evidence suggests that while there is much information at planners' disposal about the projected impacts of climate change, there have been few adaptation actions [26, 79, 104]. The explanations given for this are many and varied and include: politics [29], vested interests [5], expediency of decisions [5]; institutional path dependency [22]; mismatch of functional responsibilities e.g. through conflicts between the hierarchical levels of planning $[11,79,83]$, a 'persistent undertow' that planning should seek to meet predicted demands for growth [79]; and the lack of a conduit through which climate change concepts can be transferred from policy principles into practice[79]. Addressing these barriers will be critical for planning if it is to effectively facilitate adaptation actions.

Importantly, public awareness and acknowledgement of issues (not just climate change) is linked with the political necessity to act [3]. Thus, it has been identified that finding new ways to engage the public in discussions about growth management and their link with climate change are necessary for planning to effectively and proactively address climate change adaptation [104]. Added to this is the need to fill a void in the knowledge and capacity of planners regarding climate change adaptation, which has been identified to be lacking in some instances [29, 105]. Overall, while planning is at the source of the reasons for this challenge of 'developing conviction', it concurrently has the capacity (e.g. 1,5 and 7 from side bar 1 ) to address this challenge.

\section{Challenge 2: Facilitating equitable processes and outcomes}

In our view, there are three key equity challenges relating to planning processes and outcomes that must be grappled with in seeking to adapt to climate change. These are: intergenerational; intragenerational; and, environmental equity. These issues were made explicit considerations of sustainable development actions, and hence in many planning strategies, through the World Commission on Environment and Development [106]. Our discussion of this challenge concurrently highlights many of the capacities of planning identified in Sidebar 1, and their associated challenges in reality. For example, as identified in Table 2 (agenda/project), planning processes while beginning with positive intentions to achieve fair processes and outcomes, can be captured by political or other interests to win favour.

Intragenerational equity issues can be viewed on numerous scales: e.g local (justice between individuals of the one community), and international (equity between nations, in terms of the impacts of climate compared to contribution to climate change). For the international community, 'adaptation to climate change presents formidable dilemmas of justice' [107 p. 594]. Hence, four principles have been proposed to advance adaptation in the international community. These include: avoiding dangerous climate change; forward-looking responsibility; putting the most vulnerable first; and equal participation of all [107]. Many of the planning tools identified in Table 2 have the potential to address these issues, beginning with vision / mission statements which are then translated into other planning tools, provided they are not captured by vested interests.

The interests of citizens are not necessarily represented equally by governments and hence planning institutions, 'the most vulnerable people often have the least voice' [107 p.595]. Thus it is of critical importance to have fair processes for planning decisions regarding collective adaptation measures, and that allow effective participation [107]. In the context of sea level rise, Cole and McLaren [81] highlight major socio-economic intragenerational equity issues particularly for urban environments. 
They believe that this will give rise to fundamental questions about the distribution of scarce resources in aid of preventing damage and ameliorating effects where this in not possible.

Additionally, planners need to be cognisant that misleading predictions which are used in good faith as the basis of policy action, may cause greater economic and social losses than the physical impact itself [83].

The interests of future generations and non-human species are largely unrepresented in processes of planning and decision making, thus their interests are not reflected in the outcomes of plans and decisions $[107,108]$. This has led to calls for a clearer account of these stakeholders' role in democracy, with the acknowledgement that because of the absence of authorization, accountability and presence, and representation on behalf of nonhumans and future generations is likely to remain contested [108]. In this vein, procedural solutions that address inequities in participation in planning and decision making on adaptation to climate change have been viewed as necessary [109 p.657]. Planning has the capacity to address this challenge of facilitating equitable processes and outcomes through its many relevant capacities (e.g. 1-3 of Sidebar 1).

\section{Challenge 3: Transforming planning systems from passive to proactive}

Planning often tends to focus on the control or prevention of activities rather than being proactive [79]. Hence, a key challenge for spatial planning in addressing climate change adaptation will hence be transforming key aspects of planning systems from passive to proactive mechanisms. As discussed in Table 2 (policy/regulation/code), planning decision rules may have unintended consequences en masse, particularly if the rules are difficult to change and update. Many western planning systems with a regulatory base in development control suffer from being too passive - the force of change lies in individuals seeking to achieve their own goals, with planning passively seeking to modify this via development control [110]. In contrast, proactive planning approaches would more directly shape change and modify markets so that collective concerns such as adaptation are directly dealt with, e.g. through purposefully designed projects, policies and / or design (see Table 2). While there is a diversity of approaches to carrying out plans - they are mostly challenged by the relative irreversibility of existing settlement patterns which renders planning passive (particularly regulative systems; neo-liberal systems that preference individual choice). Climate change thus requires a shift of focus for planning, from new development, to the future of all built form over the next 50-100 years and beyond.

Hence proactively adapting existing developed areas is a key challenge. There may be more opportunities to do so in developing countries where in many contexts there is greater demand and rates of growth of new building stock [111,112]. These factors have contributed to the view that the current short term planning horizons present in many nations and jurisdictions, are largely inadequate for the long-term impacts of climate change including sea level rise [11, 83]. A key challenge will thus be the "need to shift the time horizons of political decision making into the future yet act quickly" [79]. Planning has the capacity to deal with this challenge given its many capacities identified in Sidebar 1 (e.g. 1,3 and 6). 


\section{Conclusion}

This paper has demonstrated that spatial planning is widely acknowledged to have a potentially significant role in adapting to climate change. Prior literature has identified that planning institutions are critical drivers of existing adaptation actions. Yet despite this, evidence suggests there are few adaptation processes underway, and that in practice most local governments have not begun to specifically address climate change adaptation in their plans. In this paper, we provided an overview of spatial planning - its history, and common models and tools through which its ideals are implemented.

The suite of general methods for planning for climate change adaptation presented here demonstrates how evidenced-based knowledge about the impacts of climate change can be applied spatially for action towards adaptation. The way in which these tools can be applied, and their potential benefit for adapting to climate change, will ultimately be context-specific, and tailored for the nature of the adaptation required. The nature of planning institutions and their constituent communities vary from jurisdiction to jurisdiction, thus there will be no 'one-size fits all' approach to spatial planning for adaptation. Plans which engage local communities [95] (a key step for planning for adaptation) to determine what tools should be implemented will be most likely to succeed.

This paper speaks broadly to the pitfalls and benefits of planning, by highlighting key challenges to planning for adaptation. We acknowledge our paper has limitations. It is written from a developed nations' perspective. We acknowledge the uneven growth and take up of climate change adaptation actions across the developed and developing world. Challenges in implementing adaptation are likely to be greater for developing nations, but may also offer some possibilities for greater early adaptation prior to deeper path dependency. The suite of methods we present could still be of value in these contexts. Secondly, we have identified a need for further critical research into actual cases of adaptation worldwide, appropriately classified according to planning type, local circumstance, and specific adaptation needs. The lack of documented cases restricts knowledge dissemination, theory building and empirical analysis of adaptation via planning. If supported by suitable analysis, planning offers many possibilities for adaptation to occur in ways that are integrated with wider long term social, economic and ecological goals.

\section{Notes}

${ }^{1}$ In theory and practice, the term 'spatial planning' is often used interchangeably with like terms including but not limited to 'urban planning,' 'land use planning,' 'planning,' 'urban and regional planning,' 'physical planning,' and 'town planning.' In this paper we use the term spatial planning to highlight spatial consequences these activities have.

${ }^{2}$ Climate change impacts include but are not limited to: sea level rise; increased frequency and consequences of extreme weather such as floods, drought and bushfire; loss of productive agricultural land and ecological habitat. These have both direct and indirect impacts for spatial planning. See References 1, 8 and 9 for further details. 


\section{References}

1. Intergovernmental Panel on Climate Change: Climate Change 2007: Impacts, Adaptation and Vulnerability. Contribution of Working Group II to the Fourth Assessment Report of the Intergovernmental Panel on Climate Change. (Parry M, Canziani O, Palutikof J, van der Linden P, Hanson C eds.). Cambridge: Cambridge University Press; 2007.

2. Stern N: The Economics of Climate Change. London: Cambridge University Press; 2007.

3. Giddens A: The Politics of Climate Change. Polity: Cambridge; 2009.

4. Wilson E, Piper J: Spatial planning and climate change. London: Routledge; 2010.

5. Bulkeley H: Planning and Governance of Climate Change. In Planning for Climate Change: Strategies for Mitigation and Adaptation for Spatial Planners. Edited by Davoudi S, Crawford J, Mehmood A. London: Earthscan; 2009: 284.

6. Biesbroek GR, Swart RJ, van der Knaap WGM: The mitigation-adaptation dichotomy and the role of spatial planning. Habitat International: Climate Change and Human Settlements 2009:230-237.

7. Hansen HS: Modelling the future coastal zone urban development as implied by the IPCC SRES and assessing the impact from sea level rise. Landscape and Urban Planning 2010, 98:141-149.

8. Intergovernmental Panel on Climate Change: Managing the Risks of Extreme Events and Disasters to Advance Climate Change Adaptation. (Field CB, Barros V, Stocker TF, Qin D, Dokken DJ, Ebi KL, Mastrandrea MD, Mach KJ, Plattner G-K, Allen SK, et al eds.). Cambridge: Cambridge University Press; 2012: 1075.

9. Rosenzweig C, Solecki WD, Hammer SA, Mehrotra S (Eds.): Climate Change and Cities: First Assessment Report of the Urban Climate Change Research Network. New York: Cambridge University Press; 2011.

10. Ruth M, Rong F: Research Themes and Challenges. In Smart Growth and Climate Change. Edited by Ruth M. Cheltenham, UK: Edward Elgar; 2006: 9-61.

11. Wilson E: Adapting to Climate Change at the Local Level: The Spatial Planning Response. Local Environment 2006, 11:609-625.

12. de Vries J: Climate change and spatial planning below sea-level: Water, water and more water'. Planning Theory and Practice 2006, 7:229-233.

13. Storbjörk S, Hendren J: Institutional capacity-building for targeting sea-level rise in the climate adaptation of Swedish coastal zone management. Lessons from Coastby. Ocean and Coastal Management 2011, 54:265-273.

14. Greiving S, Fleischhauer M: National Climate Change Adaptation Strategies of European States from a Spatial Planning and Development Perspective. European Planning Studies 2012, 20:27-48.

15. Measham TG, Preston BL, Smith TF, Brooke C, Goddard R, Withycombe G, Morrison C: Adapting to climate change through local municipal planning: barriers and challenges. Mitigation and Adaptation Strategies for Global Change 2011.

16. Tribbia J, Moser S: More than information: what coastal managers need to plan for climate change Environmental Science \& Policy 2008, 11:315-328.

17. McDonald J: The role of law in adapting to climate change. Wiley Interdisciplinary Reviews: Climate Change 2011, 2:283-295.

18. de Wit E, Webb R: Planning for coastal climate change in Victoria. EPLJ 2010, 27:23-35.

19. Peel J, Godden L: Planning for Adaptation to Climate Change: Landmark Cases from Australia. Sustainable Development Law and Policy 2008-2009, 37:37-41.

20. Hall P: Urban and Regional Planning. 4 edn. London: Routledge; 2007.

21. Calthorpe P: Urbanism in the age of climate change. Washington: Island Press; 2011.

22. Howard J: Climate Change Mitigation and Adaptation in Developed Nations: A Critical Perspective on the Adaptation Turn in Urban Climate Planning. In Planning for Climate 
Change: Strategies for Mitigation and Adaptation for Spatial Planners. Edited by Davoudi S, Crawford J, Mehmood A. London: Earthscan; 2009.

23. Wilson E: Developing UK Spatial Planning Policy to Respond to Climate Change. Journal of Environmental Policy and Planning 2006, 8:9-25.

24. Stone BJ: Physical Planning and Urban Heat Island Formation: How Cities Change Regional Climates. In Smart Growth and Climate Change. Edited by Ruth M. Cheltenham, UK: Edward Elgar; 2006: 318-341.

25. Davoudi S, Crawford J, Mehmood A (Eds.): Planning for Climate Change: Strategies for Mitigation and Adaptation for Spatial Planners. London: Earthscan; 2009.

26. Ford J, Berrang-Ford L, Paterson J: A systematic review of observed climate change adaptation in developed nations - a letter. Climatic Change 2011, 106:327-336.

27. Gagnon-Lebrun F, Agrawala S: Implementing adaptation in developed countries: an analysis of progress and trends. Climate Policy (Earthscan) 2007, 7:393-408.

28. Pearman GI (Ed.). Greenhouse: Planning for Climate Change. Melbourne: CSIRO Publishing; 1988.

29. Roaf S, Crichton D, Nicol F: Adapting Buildings and Cities for Climate Change: A 21st century survival guide. Oxford: Architectural Press an imprint of Elsevier; 2005.

30. Smith PF: Building for a changing climate: The Challenge for Construction, Planning and Energy. London: Earthscan; 2010.

31. Mumford L: The City in History. New York: Harcourt, Brace; 1961.

32. Morris A: History of Urban Form: Before the Industrial Revolution. New York: John Wiley; 1994.

33. Wheeler SM: Planning for Sustainability: Creating Livable, equitable and ecological communities. Milton Park, Oxon: Routledge; 2004.

34. Low NP, Gleeson B, Green RJ, Radovic D: The Green City: Sustainable Homes Sustainable Suburbs. Sydney University of New South Wales Press; 2005.

35. Howard E: To-morrow, a Peaceful Path to Reform. London: Routledge; 1898[1998].

36. Burnham DH, Bennett EH: Plan of Chicago. New York: Da Capo Press; 1909 [1970].

37. Geddes P: Cities in Evolution: an introduction to the town planning movement and to the study of civics. London: Routledge; 1998[1915].

38. March A: Institutional Impediments to Planning Professionalism in Victoria, Australia. International Planning Studies 2007, 12:367-389.

39. Hawntree M: The Emergence of the Town Planning Profession. In British Town Planning: the formative years. Edited by Sutcliffe A. Leicester: Leicester University Press; 1981: 64-105.

40. Taylor N: Urban Planning Theory Since 1945. London: Sage; 1998.

41. Rittel HWJ, Webber MM: Dilemmas in a General Theory of Planning. Policy Sciences 1973, 4:155-169.

42. Hoch C: Doing Good and Being Right - the pragmatic connection in planning theory. JAPA 1984, 50:335-343.

43. Yiftachel O: Theory and Practice in Metropolitan Planning: The Case of Perth. Perth: School of Architecture and Planning, Curtin University of Technology; 1991.

44. Simon HA: Administrative behaviour: A Study of decision making processes in administrative organisations. New York: Free Press; 1976 [1945].

45. Hoch C, Linda J, Dalton C, Frank, SS: The Practice of Local Government Planning. Washington: International City/County Management Association; 2000.

46. Klein R, Nicholls R, Mimura N: Coastal adaptation to climate change: Can the IPCC technical guidelines be applied? Mitigation and Adaptation Strategies for Global Change 1999, 4:239252.

47. Bridgman P, Davis G: The Australian Policy Handbook. 3 edn. Sydney: Allen and Unwin; 2004.

48. Meyerson M, Banfield E: Politics, Planning and the Public Interest: the case of public housiong at Chicago. New York: Free Press; 1955. 
49. Chadwick G: A Systems View of Planning. Oxford: Pergamon Press.; 1971.

50. McLoughlin B: Urban and Regional Planning: A Systems Approach. London: Faber and Faber; 1969.

51. Stevens D, Dragicevic S, Rothley K: iCity: A GIS-CA modelling tool for urban planning and decision making. Environmental Modelling \& Software 2007, 22:761-773.

52. Davidoff P: Advocacy and Pluralism in Planning. Journal of the Amrican Institute of Planners 1965, 31:331-338.

53. Hanssen G: Ensuring local community interests in market-oriented urban planning? The role of local politicians. Environment and Planning C: Government and Policy 2010, 28:714-732.

54. Harvey D: Social Justice and the City. London: Edward Arnold; 1973.

55. Falleth E, Sandkjaer Hanssen G, Saglie I: Challenges to Democracy in Market-Oriented Urban Planning in Norway. European Planning Studies 2010, 18:737-753.

56. Young IM: Justice and the Politics of Difference. Princeton: Princeton University Press.; 1990.

57. Sandercock L: Towards Cosmopolis. London: John Wiley and Sons; 1998.

58. Fincher R, Jacobs JM: Cities of Difference. New York: The Guilford Press; 1998.

59. Watson $\mathrm{V}$ : The planned city sweeps the poor away...': Urban planning and 21st century urbanisation. Progress in Planning 2009, 72:151-193.

60. Lindblom CE: The Science of Muddling-through. Public Administration Review 1959, :79-88.

61. Etzioni A: Mixed Scanning: A "Third" Approach to Decision-making. In A Reader in Planning Theory. Edited by Faludi A. Oxford: Pergamon; 1973/1967

62. Forester J: The Deliberative Practitioner: Encouraging Participatory Planning Processes. Cambridge, Massachusetts: The MIT Press; 1999.

63. Allmendinger P: Planning Theory. Basingstoke: Palgrave McMillan; 2009.

64. Stein LA: Urban Legal Problems. Sydney: The Law Book Company; 1974.

65. Williams K, Dair C: What is Stopping Sustainable Building in England? Barriers Experienced by Stakeholders in Delivering Sustainable Development. Sustainable Development 2007, 15:135-147.

66. Hopkins LD: Urban Development: The logic of making plans. Washington: Island Press; 2001.

67. Adger WN, Arnell NW, Tompkins EL: Successful adaptation to climate change across scales. Global environmental change 2005, 15:170-176.

68. Storbjork S: Governing Climate Adaptation in the Local Arena: Challenges of Risk Management and Planning in Sweden. Local Environment 2007, 12:457-469.

69. Urwin K, Jordan A: Does public policy support or undermine climate change adaptation? Exploring policy interplay across different scales of governance Global Environmental Change 2008, 18:180-191.

70. Saavedra C, Budd WW: Climate change and environmental planning: Working to build community resilience and adaptive capacity in Washington State, USA. Habitat International 2009, 33:246-252.

71. Vasey-Ellis N: Planning for Climate Change in Coastal Victoria. Urban Policy and Research 2009, 27:159-171.

72. Gurran N, Hamin E, Norman B: Planning for climate change: Leading Practice Principles and Models for Sea Change Communities in Coastal Australia. Sydney: University of Sydney. Prepared for the National Sea Change Taskforce; 2008.

73. Romero-Lankao P: Governing Carbon and Climate in the Cities: An Overview of Policy and Planning Challenges and Options. European Planning Studies 2012, 20:7-26.

74. Hastings PA, Childs IRW: Adapting to Sea-Level Rise: Lessons for the Future from Redcliffe, Australia. In Climate change, natural disasters and other catastrophes: fears and concerns for the future. Nova Science publications; 2009

75. Hamin E, Gurran N: Urban form and climate change: Balancing adaptation and mitigation in the U.S. and Australia. Habitat International 2009, 33:238-245. 
76. Pizarro R: Urban Form and Climate Change: Towards Appropriate Development Patterns to Mitigate and Adapt to Global Warming. In Planning for Climate Change: Strategies for Mitigation and Adaptation for Spatial Planners. Edited by Davoudi S, Crawford J, Mehmood A. London: Earthscan; 2009: 33-45

77. Healey P: Collaborative Planning: Shaping places in fragmented societies. London: Macmillan; 1997.

78. Hillier J: Stretching beyond the horizon: a multiplanar theory of spatial planning and governance. London: Gower; 2007.

79. Bulkeley H: A Changing Climate for Spatial Planning. Planning Theory and Practice 2006, 7:203-214.

80. Cheng A, Daniels S: Examining the Interaction Between Geographic Scale and Ways of Knowing in Ecosystem Management: A Case Study of Place-Based Collaborative Planning. Forest Science 2003, 49:841-854.

81. Cole DA, McLaren NE: Planning systems and the greenhouse effect. In Greenhouse: Planning for Climate Change. Edited by Pearman GI. Melbourne: CSIRO Publishing; 1988: 680-693

82. Adger N, Lorenzoni I, O'Brien KL: Living with Climate Change: Are there Limits to Adaptation? Cambridge: Cambridege University Press; 2009.

83. Childs IRW, Auliciems A, Hundloe TJ, McDonald GT: Socio-economic impacts of climate change: potential for decision-making in Redcliffe Queensland. In GREENHOUSE: Planning for climate change. Edited by Pearman GI. Melbourne: CSIRO Publishing; 1988: 648-664

84. Hanak E, Moreno G: California coastal management with a changing climate. Climatic Change 2011.

85. Webb J: Making climate change governable: the case of the UK climate change risk assessment and adaptation planning. Science and Public Policy 2011, 38:279-292.

86. Albrechts L: Shifts in strategic spatial planning? Some evidence from Europe and Australia, Environment and Planning A. 2006, 28:1149-1170.

87. Barnett J: Adapting to Climate Change in Pacific Island Countries: The Problem of Uncertainty. World Development 2001, 29:977-993

88. Yohe G, Neumann J: Planning for sea level rise and shore protection under climate uncertainty. Climatic Change 1997, 37:243-270.

89. Moser S: Impact assessments and policy responses to sea-level rise in three US states: An exploration of human-dimension uncertainties. Global Environmental Change 2005, 15:353369.

90. Buxton M, Haynes R, Mercer D, Butt A: Vulnerability to Bushfire Risk at Melbourne's Urban Fringe: The Failure of Regulatory Land Use Planning. Geographical Research 2011, 49:1-12.

91. Smith J: Adaptation: Another approach. EPA Journal 1990, 15.

92. Rydin E: Re-Examining the Role of Knowledge Within Planning Theory. Planning Theory 2007, 6:52-68.

93. Halsnaes K: Climate Change and Planning. Planning Theory and Practice 2006, 7:227-230.

94. Herbert K, Taplin R: Climate change impacts and coastal planning in the Sydney greater metropolitan region. Australian Planner 2006, 43:34-41.

95. Sheppard SRJ, Shaw A, Flanders D, Burch S, Weik A, Carmichael J, Robinson J, Cohen S: Future visioning of local climate change: a framework for community engagement and planning with scenarios and visualisation. Futures 2011, 43:400-412.

96. Hulme M: Problems with making and governing global kinds of knowledge. Global Environmental Change 2010, 20:558-564.

97. Cheong S-M: Policy solutions in the U.S. Climatic Change 2011, 106:57-70.

98. Garg A, Shukla PR, Kapshe M: From climate change impacts to adaptation: A development perspective for India. Natural Resources Forum 2007, 31:132-141.

99. Swart R, Raes F: Making integration of adaptation and mitigation work: mainstreaming into sustainable development policies? . Climate Policy (Earthscan) 2007, 7:289-303. 
100. Wilson C, McDaniels T: Structured decision-making to link climate change and sustainable development. Climate Policy (Earthscan) 2007, 7:353-370.

101. Flyvbjerg B: Rationality and Power: Democracy in Practice. London: University of Chicago Press (English Edition); 1998.

102. Fainstein S: The Just City. Cornell: Cornell University Press; 2010.

103. Campbell H: Is the Issue of Climate Change too Big for Spatial Planning? Planning Theory and Practice 2006, 7:201-203.

104. Robinson P: Canadian Municipal Response to Climate Change: Measurable Progress and Persistent Challenges for Planners. Planning Theory and Practice 2006, 7:218-223.

105. Hurlimann AC: Responding to environmental challenges: an initial assessment of higher education curricula needs by Australian planning professionals. Environmental Education Research 2009, 15:643-659.

106. World Commission on Environment and Development: Our Common Future. Oxford: Oxford University Press; 1987.

107. Paavola J, Adger WN: Fair Adaptation to Climate Change Ecological Economics 2006:594-604.

108. O'Neill J: Representing people, representing nature, representing the world. Environment and Planning C: Government and Policy 2001, 19:483- 500.

109. Paavola J: Science and social justice in the governance of adaptation to climate change. Environmental Politics 2008, 17:644-659.

110. Stein LA: Urban Legal Problems Sydney: The Law Book Company; 1974.

111. Revi A: Climate change risk: an adaptation and mitigation agenda for Indian cities Environment and Urbanization 2008, 20:207-229.

112. Rannow S, Loibl W, Greiving S, Gruehn D, Meyer BC: Potential impacts of climate change in Germany - Identifying regional priorities for adaptation activities in spatial planning.

Landscape and Urban Planning 2010, 98:160-171

Figure 1: Rational Comprehensive Planning: a common model providing guidance for planning activities

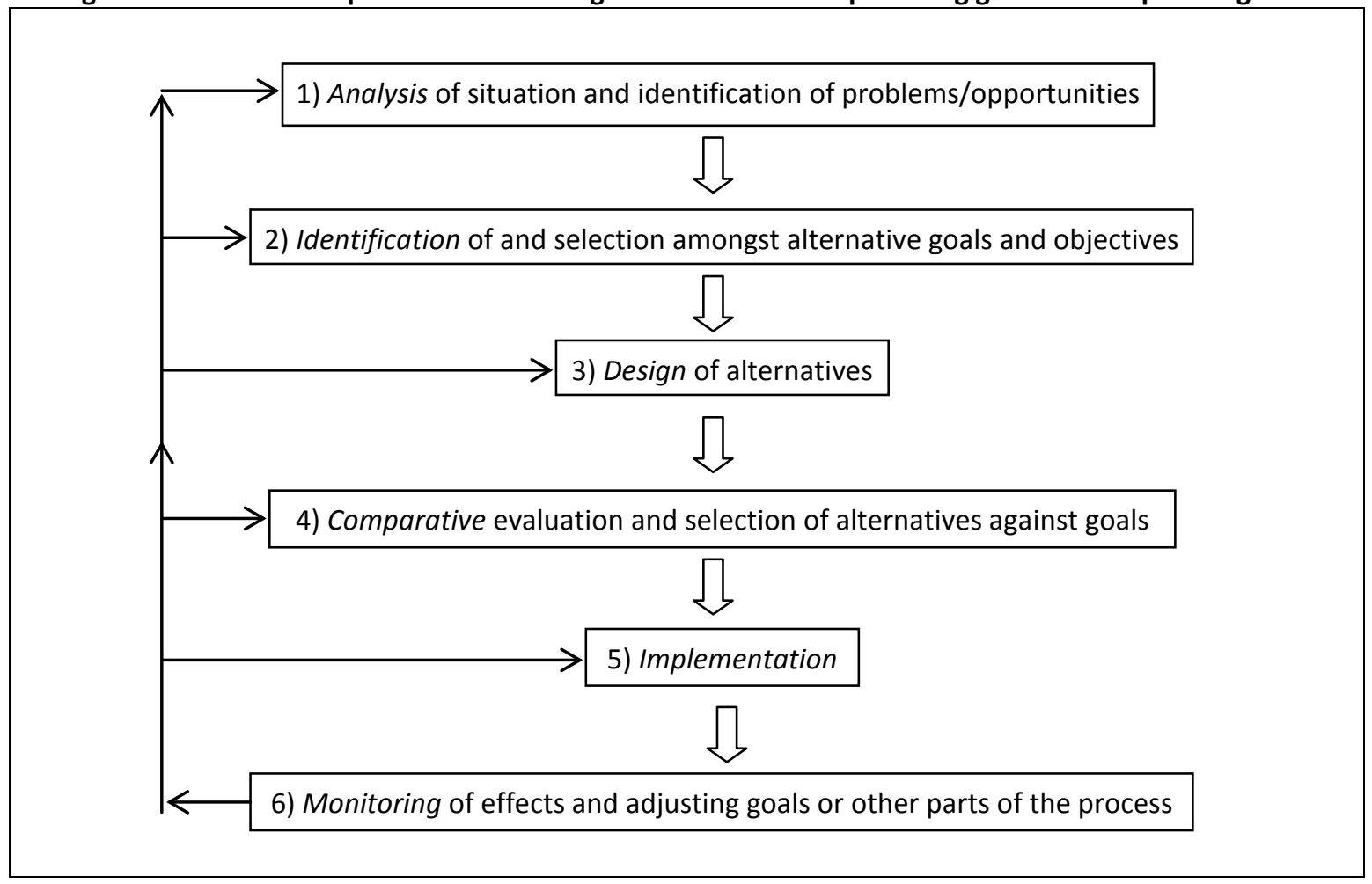

Developed from [41 and 44] 
Tables

Table 1: Examples of planning tools

\begin{tabular}{|l|l|}
\hline Planning Tool Types & General description \\
\hline Vision/ Mission Statement & $\begin{array}{l}\text { General statement of desired future outcomes to provide broad overall } \\
\text { directions and motivations }\end{array}$ \\
\hline Strategy Planning & $\begin{array}{l}\text { System of allowing broad directional change as needs or opportunities } \\
\text { arise, or new knowledge is developed. Achieves benefits from coordination } \\
\text { and acknowledging interdependence of a variety of plan components \& } \\
\text { tools. }\end{array}$ \\
\hline Agenda/Project Based & Specific activities and projects to be undertaken. \\
\hline Policy/Regulation/Code & $\begin{array}{l}\text { Predetermined decision making rules to provide fairness and consistency } \\
\text { and possibly to coordinate individual actions to achieve wider goals. }\end{array}$ \\
\hline Design & $\begin{array}{l}\text { Determination of specific actions, structures or outcomes for specific places } \\
\text { or conditions. }\end{array}$ \\
\hline
\end{tabular}

Developed from [62] 
Table 2: Methods for adaptation planning

\begin{tabular}{|c|c|c|}
\hline $\begin{array}{l}\text { Planning tool } \\
\text { types }\end{array}$ & Description / example applied to adaptation & $\begin{array}{l}\text { Discussion } \\
\text { Pros (+) and Cons (-) }\end{array}$ \\
\hline $\begin{array}{l}\text { Vision/ Mission } \\
\text { Statement }\end{array}$ & $\begin{array}{l}\text { In adapting to climate change, the city will } \\
\text { provide conditions for social justice, equality of } \\
\text { access and environmental sustainability. }\end{array}$ & $\begin{array}{l}+ \text { Useful as a starting point for stating intent, organizing and finding common ground between large } \\
\text { sets of differing views or stakeholders. } \\
\text { - Attention at a high level of abstraction alone can avoid dealing with practical realities, and may } \\
\text { distract attention from the difficulties and mechanisms of implementation. }\end{array}$ \\
\hline Strategy Planning & $\begin{array}{l}\text { Decision making process for adaptation that } \\
\text { can modify investments e.g. from existing } \\
\text { urban form to an evidence based urban form } \\
\text { which facilitates adaptation. Doing so while } \\
\text { continuing to coordinate overall growth and } \\
\text { investments patterns to complement this } \\
\text { change. }\end{array}$ & $\begin{array}{l}+\quad \text { Provides the ability to change the direction of decision-making to new and more sustainable paths } \\
+\quad \text { Allows for understandings to be developed, and gathering and analysis of evidence at wider scales, } \\
\text { appreciating the role of many inter-dependent 'systems' } \\
+\quad \text { Provides a base for decisions that may be unpopular for some, but are justified collectively or in the } \\
\text { longer term. } \\
-\quad \text { Can require strong centralised 'force' that over-rides local innovation and adaptation ideas or } \\
\text { encourages dependencies } \\
-\quad \text { Centralised structures can atrophy and impede change } \\
-\quad \text { Can be captured by competing political ideologies }\end{array}$ \\
\hline $\begin{array}{l}\text { Agenda/Project } \\
\text { Based }\end{array}$ & $\begin{array}{l}\text { Public funded relocation of a vulnerable } \\
\text { community (e.g. at risk of future exposure to / } \\
\text { currently impacted by extreme whether events) }\end{array}$ & $\begin{array}{l}+\quad \text { Provides ability for direct and decisive action } \\
\text { - } \quad \text { May not be part of a reasoned and coordinated plan, particularly if captured by political or other } \\
\text { interests to win favour (hence may change radically through political cycles) }\end{array}$ \\
\hline $\begin{array}{l}\text { Policy/Regulation/ } \\
\text { Code }\end{array}$ & $\begin{array}{l}\text { Regulatory rules that ensure individual building } \\
\text { permits are given to achieve land use patterns } \\
\text { that complement strategic planning and } \\
\text { achieve successful adaptation. E.g. permits } \\
\text { given for high density housing that incorporates } \\
\text { passive design elements to increase thermal } \\
\text { comfort without the need for electricity inputs; } \\
\text { restriction of housing located outside walking } \\
\text { distance from mass transit options. }\end{array}$ & $\begin{array}{l}+\quad \text { Can ensure relative consistency and fairness over an entire system, particularly when 'hard' rules } \\
\text { provide clear tests of achievement } \\
+\quad \text { Can provide means of coordinating many individual incremental changes over long time periods } \\
\text { towards goals. } \\
\text { - Decision rules may have unintended consequences en masse, particularly as conditions change, if } \\
\text { rules do not account for local particularity, if rules are difficult to change and update, or if users } \\
\text { develop 'work arounds'. } \\
\text { - Rules may be 'balanced-off' against other goals, reducing their impact }\end{array}$ \\
\hline Design & $\begin{array}{l}\text { Detailed engineering and architectural design } \\
\text { of urban form to ensure that settlements are: } \\
\text { resilient to extreme weather events; and that } \\
\text { services are integrated, with walkable access to } \\
\text { city centre and employment. }\end{array}$ & $\begin{array}{l}+\quad \text { Locally tailored and specific solutions can deliver high quality and situation-specific outcomes. } \\
+\quad \text { Ability to draw on a range of professionals and range of other expertise. } \\
-\quad \text { More expensive, difficult and time consuming to deliver at large scale across entire systems, and the } \\
\text { tendency to copy or transplant can lead to locally inappropriate outcomes. } \\
\text { - Often delivered only in costly projects that can bear additional expense, and often abandoned in } \\
\text { difficult financial times }\end{array}$ \\
\hline
\end{tabular}




\section{Further Reading/Resources}

Readers may be interested in the following planning policies / guidance documents which address climate change.

- United Kingdom: Office of the Deputy Prime Minister (2004) The Planning Response to Climate Change - Advice on Better Practice. Available on line at:

http://www.communities.gov.uk/documents/planningandbuilding/pdf/147597.pdf

- United States of America: American Planning Association. 2011 American Planning Association Policy Guide on Planning and Climate Change. Available on line at:

http://www.planning.org/policy/guides/pdf/climatechange.pdf 